\title{
Impact of Brand Awareness and Customer Satisfaction Towards Services of Jan Aushadhi Medicalstores
}

\author{
Milton Solomon C, Dr. C. Sundar
}

\begin{abstract}
This study focused on 'Jan Aushadhi Scheme' launched by the government of India. It is the need of the hour to understand the knowledge level of the consumer about generic medicine to promote the product and services across the various region in India. The purpose of the study is to identify the service of the stores by way of assessing service quality, brand awareness and customer satisfaction to offer suitable marketing strategies to the Jan Aushadi Medical Stores.
\end{abstract}

Index Terms: Jan Aushadhi Medical Stores, Brand Awareness, Customer Satisfaction, SERVQUAL, Demographic Factors.

\section{INTRODUCTION}

In the changing retail landscape, the pharmaceutical sector is highly competitive. The pharmacies play a vital role in providing pharmaceutical services required for the healthcare of the patients and it is an effective factor in the economy and development of the nation. Today consumers can buy medicine from both online and offline. They can buy medicine from both private and public players such as small independent pharmacies, branded Pharmacy andgovernment-owned stores. Most of the branded stores, developing strategies to attract and retain customers to increase their market share as well to gain their loyalty and maintain a relationship.

This study focused on 'Jan Aushadhi Scheme' launched by the government of India. Jan Aushadhi scheme is established to make the availability of quality generic medicines at affordable prices to all, especially to the poor, throughout the country, through outlets known as Jan Aushadhi Stores (JASs). According to Hindustan Times, 2018, "The government's flagship programme promoting the use of generic drugs, Jan Aushadhi, will reach all the districts in India by mid-August. The generic drug stores have already opened in 612 of the 717 districts in India under the Pradhan MantriBharatiya Jan AushadhiPariyojna (PMBJP).”

The report of Bureau of Pharma Public Sector Undertakings (BPPI) highlighted that Jan Aushadhi stores sell over 900 medicines and 150 surgical items at discounted prices, compare to market rate, this store sells $20-30 \%$ cheap. The store numbers also raised from 80 to 3872 in the last four years. The authorities also aimed at reaching all districts in India by the end of this year.

It is important to understand the knowledge level of the

Revised Manuscript Received on July 05, 2019.

Milton Solomon C, Department of Management Studies, SRM University, Katangulathur, Tamizhnadu, India. Ramapuram, Chennai.
Dr. C. Sundar, Department of management Studies SRM University,

consumer about generic medicine to promote the product and services across the various region in India. It is also to be noted that most of the stores lost its attraction due to unavailability of prescribed generic medicine in Jan Aushadhi Medicine stores across India. Before opening many outlets, the government has to initiate a market survey to find out why the store lost it attraction or on satisfying customers i.e. on Branding or Service.

\section{REVIEW OF LITERATURE}

Some of the related literature was reviewed for an understanding of the research area

Alhuwitat and Salem (2017) suggested to create a direct impact on customer perceived value, satisfaction and loyalty with the pharmaceutical services, the marketerneeds to build a strong relationship with customers

Lee, Godwin, Kim and Lee (2015) conducted a cross-sectional evaluation using the data of the year2008 Korean National Health and Nutrition Examination Survey (KNHANES) to assess the predictive factors for patient satisfaction with pharmacy services. The authors found that three out of four patients expressed satisfaction toward pharmacy services. Middle to low family incomes, the fair perception of health, and employee insured individuals were significant predictors of patient satisfaction with pharmacy services.

Bahrinizadeh, EsmaiilpoorandHaraghi(2014) investigated the country of origin effects on brand equity and its dimensions in a pharmaceutical product. The resultshighlighted that Country of origin effects has a direct and positive impact on brand awareness, perceived quality, brand loyalty, brand equity. And the country of origin effects has an indirect and positive impact on brand equity through brand awareness, brand image, brand loyalty. Furthermore, the authors suggested that marketing managers in the pharmaceutical industry should pay attention tothe country of origin because it creates brand value for the pharmacist.

Parasuraman, Zeithaml, and Berry (1986) developed a service quality instrument called SERVQUAL, which evaluated consumer perceptions of services. Factor analysis of consumer responses to SERVQUAL resulted in a conclusion that there are 5 key dimensions of service quality. They are

- Reliability - the ability to deliver promised services in a dependable, accurate manner.

- Responsiveness - the willingness to help customers and provide prompt service. 
- Empathy - the degree to which customers are treated as individuals.

- Assurance - the ability to inspire trust and confidence.

- Tangibles - physical elements of the service such as facilities and equipment.

Hassali et al., (2009) reviewed the literature from 1970 to 2008 on consumers' knowledge, attitudes and opinions of the use of generic medicines. The study was an "evident from the divergence of views observed by country development level, consumers' socioeconomic characteristics, drug product characteristics, pharmaceutical reimbursement system, policy environment, contact with health care professionals, past experience with medications, and knowledge of the seriousness of a medical condition. Patient confidence and knowledge pertaining to generic medicines use have increased over the past four decades, especially in developed countries. Mass educational efforts, financial incentives, and greater communication among patients and healthcare professionals were seen as major drivers to the uptake of generic medicines among consumers".

From the above literature, it is identified that customer satisfaction and study of brand awareness of Jan Aushadhi stores is not undertaken so far. So, it is important to identify the service of the stores to tap the market potential across various places by way of assessing service quality, brand awareness and customer satisfaction to maintain sustainable market share.

\section{OBJECTIVES OF THE STUDY}

The broad objectives of the study are followed as

- To identify the determinants of services of Jan Aushadhi Medical stores

- To measure the relationship between brand awareness and customer satisfaction towards services of Jan Aushadhi Medical Stores

- $\quad$ To examine the association between knowledge level of generic medicine, level of customer satisfaction, awareness of Jan Aushadhi Medical stores with respect to demographic factors of the respondents

- To find out the significant association between pricing policy with respect to Satisfaction Level, Knowledge level of Generic Medicines and Awareness Level of Jan AushadhiMedicalStores

- To offer suitable marketing strategies forJan Aushadhi Medical Stores.

\section{RESEARCH METHODOLOGY}

The research is descriptive in nature, both primary and secondary source of data is used in this study. Secondary data was collected from relevant books, documents, journals, internet related to the study. The questionnaire method was used to collect data from respondents as a primary source. The first part of questionnaire is related to the demographic profile of the respondent and second part of the questionnaire contains likert's scale type question used to identify patient perception towards services and awareness about Jan Aushadhi medical stores. The questionnaire was developed by the researcher on the basis of extensive literature review and by the input of industry people. The researcher adopted convenience sampling method to ensure the representation of all areas of Pondicherry due to their suitability for achieving the study objective, 120 responses were collected from consumersresided in Pondicherry.

The patient satisfaction with the services of JanAushadhi Medical Stores was assessed on a 5-level Likert scale: 1- very satisfied; 2- satisfied; 3- neutral; 4- dissatisfied; and 5- very dissatisfied with 11 basic items of SERQUAL instrument developed by Parasuraman, Zeithaml, and Berry (1988). Likewise, Brand Awareness is measured by 5-level Likert scale: 1-Strongly Agree; 2-Agree; 3- neutral; 4- disagree; and 5 - strongly disagree with 5 basic items based on the literature survey. For analytic purposes, the medians scores of the patients' satisfaction and brand awareness were computed due to an ordinal nature of the outcome variable.

\section{ANALYSIS AND DISCUSSION}

The data collected were analysed using SPSS and the results of the study were discussed below:

Table 1. Demographic Profile of the Respondents

\begin{tabular}{|c|c|c|c|}
\hline \multicolumn{2}{|c|}{ Demographic Variable } & $\begin{array}{c}\text { Frequenc } \\
\mathbf{y}\end{array}$ & $\begin{array}{c}\text { Percentag } \\
\text { e }\end{array}$ \\
\hline \multirow{3}{*}{ Gender } & Male & 72 & 60.0 \\
\hline & Female & 48 & 40.0 \\
\hline & Total & 120 & 100.0 \\
\hline \multirow{4}{*}{ Age } & $\begin{array}{ll}\text { Below } 35 \\
\text { years }\end{array}$ & & 6.7 \\
\hline & $\begin{array}{ll}35-50 \\
\text { years }\end{array}$ & 56 & 46.7 \\
\hline & $\begin{array}{l}\text { Above } 50 \\
\text { years }\end{array}$ & 56 & 46.7 \\
\hline & Total & 120 & 100.0 \\
\hline \multirow{4}{*}{$\begin{array}{l}\text { Educatio } \\
\mathbf{n}\end{array}$} & $\begin{array}{l}\text { Below } \\
\text { Graduatio } \\
\mathrm{n}\end{array}$ & 20 & 16.7 \\
\hline & $\begin{array}{l}\text { Under } \\
\text { Graduatio } \\
\mathrm{n}\end{array}$ & 72 & 60.0 \\
\hline & $\begin{array}{l}\text { Post } \\
\text { Graduatio } \\
\mathrm{n}\end{array}$ & 28 & 23.3 \\
\hline & Total & 120 & 100.0 \\
\hline \multirow{4}{*}{$\begin{array}{l}\text { Family } \\
\text { Income }\end{array}$} & $\begin{array}{l}\text { Above } \\
\text { Rs.50000 }\end{array}$ & 8 & 6.7 \\
\hline & $\begin{array}{l}\text { Rs. } 25000 \\
\text { - Rs. } 50000 \\
\end{array}$ & 32 & 26.7 \\
\hline & $\begin{array}{l}\text { Below } \\
\text { Rs.25000 }\end{array}$ & 80 & 66.7 \\
\hline & Total & 120 & 100.0 \\
\hline \multirow{4}{*}{$\begin{array}{l}\text { Number } \\
\text { of Family } \\
\text { Members }\end{array}$} & $\begin{array}{l}2-3 \\
\text { Numbers }\end{array}$ & 16 & 13.3 \\
\hline & $\begin{array}{l}3-5 \\
\text { Numbers }\end{array}$ & 84 & 70.0 \\
\hline & $5 \&$ More & 20 & 16.7 \\
\hline & Total & 120 & 100.0 \\
\hline
\end{tabular}

The above table -2 describes the demographic profile of the 120 respondents participated in the survey. With respect to gender, $60 \%$ were male and the remaining $40 \%$ were female. With respect to age, $83.4 \%$ percent of the respondents were above 35 years and the remaining $6.7 \%$ belonged to the age group of less than 35 years. With respect to education, most of the respondents were undergraduates $(60 \%)$, followed by $23.3 \%$ were post graduated and the remaining $16.7 \%$ were below graduates. With regards to family income, majority of the respondents $(66.7 \%)$ falls in the below Rs.25000 income category, followed by Rs. 25000 - Rs.50000 Income category (26.7\%) and above Rs.50,000 (6.7\%). With respect to number of family members, $70 \%$ of the respondents living with the family members of $3-5$ members, $16.7 \%$ with above 5 
members in the family and only $13.3 \%$ of respondents live in the nuclear family were only 2-3 members in the family.

JAN AUSHADHI STORES

Table 2. Jan Aushadhi Stores

\begin{tabular}{|c|c|c|c|}
\hline \multicolumn{2}{|c|}{ Jan Aushadhi Stores } & Frequency & $\begin{array}{c}\text { Percentag } \\
\text { e }\end{array}$ \\
\hline \multirow{5}{*}{$\begin{array}{l}\text { Low Pricing } \\
\text { Policy of } \\
\text { Jan } \\
\text { Aushadhi } \\
\text { Stores }\end{array}$} & 30 to $40 \%$ & 8 & 6.67 \\
\hline & 40 to $50 \%$ & 9 & 7.5 \\
\hline & 50 to $60 \%$ & 26 & 21.67 \\
\hline & 60 to $70 \%$ & 77 & 64.17 \\
\hline & Total & 120 & 100 \\
\hline \multirow{6}{*}{$\begin{array}{l}\text { Source of } \\
\text { Information }\end{array}$} & Pamphlet & 9 & 7.5 \\
\hline & $\begin{array}{l}\text { TV } \\
\text { Advertisement }\end{array}$ & 38 & 31.67 \\
\hline & $\begin{array}{ll}\text { Word } & \text { of } \\
\text { Mouth } & \\
\end{array}$ & 27 & 22.5 \\
\hline & $\begin{array}{l}\text { Doctor } \\
\text { Informed }\end{array}$ & 12 & 10.0 \\
\hline & $\begin{array}{l}\text { Other } \\
\text { Personal } \\
\text { Sources } \\
\end{array}$ & 34 & 28.33 \\
\hline & Total & 120 & 100.0 \\
\hline \multirow{3}{*}{$\begin{array}{l}\text { Awareness } \\
\text { about Jan } \\
\text { Aushadhi } \\
\text { Stores }\end{array}$} & Yes & 106 & 88.3 \\
\hline & No & 14 & 11.7 \\
\hline & Total & 120 & 100.0 \\
\hline \multirow{3}{*}{$\begin{array}{l}\text { Level of } \\
\text { Satisfaction } \\
\text { with Jan } \\
\text { Aushadhi } \\
\text { Stores }\end{array}$} & Low & 56 & 46.7 \\
\hline & High & 64 & 53.3 \\
\hline & Total & 120 & 100.0 \\
\hline Knowledge & High & 88 & 73.3 \\
\hline
\end{tabular}

\begin{tabular}{|l|l|c|c|}
\hline $\begin{array}{l}\text { Level about } \\
\text { Generic } \\
\text { Medicines }\end{array}$ & Low & 32 & 26.7 \\
\cline { 2 - 4 } & Total & $\mathbf{1 2 0}$ & $\mathbf{1 0 0 . 0}$ \\
\hline
\end{tabular}

The above table -2 describes about the opinion about Jan Aushadhi Stores.

Low Pricing Policy of Jan Aushadhi Stores: Out of 120 respondents, $64.17 \%$ of the respondents opined that compare to other medical stores, the cost of medicine is 60 to $70 \%$ less followed by $21.67 \%$ believes the price is comparatively less than $50-60 \%, 7.5 \%$ believes $40-50 \%$ price is less and only $6.67 \%$ stated 30 to $40 \%$ less in price.

Source of Information: Out of 120 respondents, $31.67 \%$ opined tv advertisement is the major source of information about Jan Aushadhi Medical Stores, followed by $28.33 \%$ said other personal sources like friends, family members, neighbours and others, $22.5 \%$ mentioned words of mouth, $10 \%$ informed doctor informed about the stores, and $7.5 \%$ got information about Jan Aushadhi stores through pamphlet.

Awareness about Jan Aushadhi Stores: Out of 120 respondents, $88.3 \%$ of the respondents were aware of Jan Aushadhi Stores and the remaining $11.7 \%$ were not aware of Jan Aushadhi Medical Stores.

Level of Satisfaction with Jan Aushadhi Stores: Out of 120 respondents, $53.3 \%$ of the respondents were highly satisfied with Jan Aushadhi Stores and the remaining 46.7\% were not level of satisfaction is low with Jan Aushadhi Medical Stores. Knowledge Level about Generic Medicines: Out of 120 respondents, $73.3 \%$ of the respondents were knowledge level about generic medicine is high about generic medicine and the remaining $26.7 \%$ were not aware of generic medicine.

DETERMINANTS OF CUSTOMER SATISFACTION ON SERVICES OF JAN AUSHADHI MEDICAL STORES

Tab le 3: Results of Factor Analysis liability Test

\begin{tabular}{|c|c|c|c|c|}
\hline $\begin{array}{l}\text { Factors } \\
\text { Name }\end{array}$ & Items & $\begin{array}{l}\text { Factor } \\
\text { Loadings }\end{array}$ & $\begin{array}{l}\text { Percentage } \\
\text { of Variance }\end{array}$ & Eigen Value \\
\hline \multirow{3}{*}{ Accessibility } & Issuing of medicines quickly & 0.875 & \multirow{3}{*}{$25.174 \%$} & \multirow{3}{*}{3.312} \\
\hline & Access to the medical shop & 0.848 & & \\
\hline & $\begin{array}{l}\text { Transportation facilities for the return } \\
\text { visit }\end{array}$ & 0.809 & & \\
\hline \multirow{3}{*}{ Tangibility } & The effectiveness of the medicines & 0.910 & \multirow{3}{*}{$21.193 \%$} & \multirow{3}{*}{2.228} \\
\hline & Packing of medicines & 0.853 & & \\
\hline & Visual appearance of the tablet capsule & 0.580 & & \\
\hline \multirow{2}{*}{ Reliability } & Availability of medicines at all times & 0.875 & \multirow{2}{*}{$20.158 \%$} & \multirow{2}{*}{1.356} \\
\hline & Availability of medicines & 0.828 & & \\
\hline \multirow{2}{*}{ Responsiveness } & Customer Benefits & 0.725 & \multirow{2}{*}{$12.507 \%$} & \multirow{2}{*}{1.008} \\
\hline & Behaviour of staff & -0.680 & & \\
\hline \multicolumn{4}{|c|}{$\begin{array}{ll}\text { Cronbach Alpha Value } \\
\end{array}$} & 0.758 \\
\hline \multicolumn{4}{|c|}{ Kaiser-Meyer-Olkin Measure of Sampling Adequacy. } & 0.619 \\
\hline \multicolumn{4}{|c|}{ Total Variance Explained } & $\mathbf{7 0 . 0 3 2 \%}$ \\
\hline
\end{tabular}

Service quality is a focused evaluation that reflects the customer's perception of specific dimensions of service namely reliability, responsiveness, assurance, empathy, tangibles (Zeithaml and Bitner, 2003). Service quality assessment helps the marketers to find out where they lagging in services to solve the problem promptly and improve their services to satisfy the customer expectation. In this study,
Factor analysis on ten items of service attributes extracted four factors which accounted for $70.032 \%$ of the total variance with the total of 7.904 eigen values, 0.619 Kaiser-Meyer-Olkin Measure of Sampling Adequacy value (KMO) which indicates the meritorious level of 
prediction. Furthermore, the significance level of Bartlett's Test of Sphericity (BTS) was 0.000. KMO and BTS tests also show that the data meet the fundamental requirements of factor analysis. The overall Cronbach's alpha coefficient was 0.752, which is considered as an acceptable level. The factor loadings ranged from 0.910 to -0.680 and the factors were labelled based on the statements loaded.

The four factors were named Accessibility, Tangibility, Reliability and Responsiveness. They are explained below

- Accessibility: According to World Health Organisation, Accessibility "is understood as the availability of good health services within reasonable reach of those who need them and of opening hours, appointment systems and other aspects of service organization and delivery that allow people to obtain the services when they need them". The factor loadings ranged from 0.809 to 0.875 with the variance of $25.174 \%$ and 3.312 eigen value. The items loaded under this factor are the medical shops issue the medicines quickly, it is easy to access the medical shop and transportation facilities for the return visit

- Tangibility: Tangibility is defined as "appearance of physical facilities, equipment, personnel, and communication materials" (Zeithaml, Parasuraman and Berry,1985). The factor loadings ranged from 0.580 to 0.910 with the variance of $21.193 \%$ and 2.228 eigenvalue. The items loaded under this factor are the effectiveness of medicines, Packing of medicines and visual appearance of the tablet capsule.

- Reliability: Reliability is defined as "the ability to perform the promised service dependably and accurately" (Zeithaml, Parasuraman and Berry,1985). The factor loadings ranged from 0.828 to 0.875 with the variance of $20.158 \%$ and 1.356 eigenvalue. The items loaded under this factor are Availability of medicines all the times and Availability of Medicines.

- Responsiveness: Responsiveness is defined as "Willingness to help customers and provide prompt service" (Zeithaml, Parasuraman and Berry,1985). The factor loadings ranged from - 0.680 to 0.725 with the variance of $12.507 \%$ and 1.008 eigenvalue. The items loaded under this factor are consumer benefit and behaviour of the staff. It is to be noted that behaviour of the staff at Jan Aushadhi store is impacting negatively. So, the stores need to focus on employee behaviour to improve customer satisfaction.

\section{BRAND AWARENESS ABOUT JAN AUSHADHI MEDICAL STORES}

Brand awareness is "the extent to which consumers are familiar with the distinctive qualities or image of a particular brand of goods or services" (Oxford University Press 2011). The descriptive statistics of the data were computed using SPSS, to knowthe mean score and standard deviation of brand awareness of Jan Aushadhi Medical Stores.

Table 4: Descriptive Statistics for Brand Awareness

\begin{tabular}{|c|c|c|}
\hline \multicolumn{3}{|c|}{ Descriptive Statistics } \\
\hline & Mean & $\begin{array}{c}\text { Std. } \\
\text { Deviation }\end{array}$ \\
\hline $\begin{array}{c}\text { This brand's logo is very } \\
\text { easy to recognize }\end{array}$ & 3.99 & .736 \\
\hline This brand is popular & 3.47 & .788 \\
\hline $\begin{array}{c}\text { I have an opinion about } \\
\text { this brand }\end{array}$ & 3.32 & .920 \\
\hline
\end{tabular}

\begin{tabular}{|c|c|c|}
\hline I have heard of this brand & 3.74 & .769 \\
\hline $\begin{array}{c}\text { Compare with other } \\
\text { brands, this brand satisfies } \\
\text { my basic needs. }\end{array}$ & 3.48 & .984 \\
\hline
\end{tabular}

The mean scores revealed that "The brand logo is very easy to recognize" (3.99) is the most important feature for brand awareness, followed by "I have heard about this brand" (3.74) have the highest value. The least score is for "The brand is popular" (3.47); "Compare to other brands, this brand satisfies my basic needs" (3.48) and "I have an opinion about this brand" (3.32). The standard deviation of all the statements is less than one which shows that there are lesser variations in the brand awareness about Jan Aushadhi Medicine Stores. Lesser the standard deviation, the better it is.

IMPACT OF CUSTOMER SATISFACTIONAND BRAND AWARENESS TOWARDS SERVICES OF JAN AUSHADHI STORES

In this section, results of the regression analysis were discussed in detail. The dependent variables are customer satisfaction (Model 1) and brand awareness (Model 2); independent variables are responsiveness, tangibility, accessibility and reliability which are listed below.

Table 5: Results of Regression Analysis

\begin{tabular}{|r|c|c|}
\hline $\begin{array}{c}\text { Independent } \\
\text { variable }\end{array}$ & $\begin{array}{c}\text { Dependent Variable } \\
\text { Customer } \\
\text { Satisfaction } \\
\text { (Model 1) }\end{array}$ & $\begin{array}{c}\text { Brand } \\
\text { Awareness } \\
\text { (Model 2) }\end{array}$ \\
\hline (Constant) & $\mathbf{8 . 8 4 9 * *}$ & $\mathbf{2 . 6 6 6} * *$ \\
\hline Responsiveness $\left(\mathrm{X}_{1}\right)$ & $\mathbf{- 0 . 2 4 5 * *}$ & 0.013 \\
\hline Tangibility $\left(\mathrm{X}_{2}\right)$ & $\mathbf{- 0 . 2 4 2} * *$ & -0.039 \\
\hline Accessibility $\left(\mathrm{X}_{3}\right)$ & -0.058 & -0.108 \\
\hline Reliability $\left(\mathrm{X}_{4}\right)$ & -0.016 & -0.024 \\
\hline $\mathbf{R}^{\mathbf{2}}$ & 0.600 & 0.079 \\
\hline $\mathbf{R}$ Value & 0.783 & 0.281 \\
\hline F Statistics & $\mathbf{4 5 . 5 5 5 * *}$ & $\mathbf{2 . 4 5 9 *}$ \\
\hline $\mathbf{N}$ & 120 & 120 \\
\hline
\end{tabular}

Impact of Customer Satisfaction with the services of Jan Aushadhi Stores

Null Hypothesis: There is no significant relationship between the services of Jan Aushadhi Medical Stores with respect to Patient/Customer Satisfaction.

The above table shows that regression results of model 1, the value of $R$ is 0.783 while $R^{2}$ interpreted 0.600 of the variances of the dependent variable, representing that $(60.0 \%)$ of variation in building a strong relationship between customer satisfaction and services of Jan Aushadhi Medical Stores. Furthermore, the other dimensions do not have a significant relationship between the dependent and independent variable except on tangibility. The results of $\mathrm{F}$ Statistics reveal that the services of medical store and customer satisfaction have a significanteffect on one another $(\mathrm{F}=45.555, \mathrm{p}<0.001)$ at $1 \%$ level of significance, which indicates that the regression model seems to be acceptable.

The regression equation is $y=8.849-0.245\left(X_{1}\right)-0.242\left(X_{2}\right)$ - $0.058\left(X_{3}\right)-0.016\left(X_{4}\right)$

Hence, it is concluded that there is a significant relationship between the services of Jan Aushadhi Medical Stores and Patient/Customer Satisfaction. 
Impact of Brand Awareness with the Services of Jan Aushadhi Stores

Null Hypothesis: There is no significant relationship between the services of Jan Aushadhi Medical Stores with respect to Brand Awareness.

The above table shows that regression results of model 2, the value of $\mathrm{R}$ is 0.281 while $\mathrm{R}^{2}$ interpreted 0.079 of the variances of the dependent variable, representing that $(7.9 \%)$ of variation in building a strong relationship between brand awareness and services of Jan Aushadhi Medical Stores. Furthermore, the other dimensions do not have a significant relationship between the dependent and independent variable. The results of F Statistics reveal that the services of medical store and customer satisfaction have a significant effect on one another $(\mathrm{F}=2.459, \mathrm{p}<0.05)$ at $5 \%$ level of significance, which indicates that the regression model seems to be acceptable.

The regression equation is $y=2.666+0.013\left(X_{1}\right)-0.039\left(X_{2}\right)$ - $0.108\left(X_{3}\right)-0.024\left(X_{4}\right)$

Hence, it is concluded that there is a significant relationship between the services of Jan Aushadhi Medical Stores and Brand Awareness.

ASSOCIATION BETWEEN KNOWLEDGE, SATISFACTION,AWARENESS OF JAN AUSHADHI STORES WITH RESPECT TO DEMOGRAPHIC VARIABLES

Table 6: Results of Chi-Square test on Demographic Variable Vs. Knowledge Level about Generic Medicine

\begin{tabular}{|l|c|c|c|}
\hline \multirow{2}{*}{$\begin{array}{l}\text { Demographi } \\
\text { c Variable }\end{array}$} & $\begin{array}{c}\text { Knowledge Level } \\
\text { about Generic } \\
\text { Medicine }\end{array}$ & $\begin{array}{c}\text { Level of } \\
\text { Satisfaction }\end{array}$ & $\begin{array}{c}\text { Awareness } \\
\text { about Jan } \\
\text { Aushadhi } \\
\text { Stores }\end{array}$ \\
\hline Gender & $\mathbf{4 . 0 9 1 *}$ & $\mathbf{5 . 7 1 4} *$ & 0.121 \\
\hline Age & $\mathbf{8 . 9 6 1 *}$ & $\mathbf{7 . 5 0 0} *$ & $\mathbf{6 . 6 7 7 *}$ \\
\hline Education & $\mathbf{6 6 . 1 0 4 * *}$ & $\mathbf{1 2 . 7 5 5 * *}$ & 5.252 \\
\hline $\begin{array}{l}\text { Family } \\
\text { Income }\end{array}$ & $\mathbf{1 6 . 7 0 5 * *}$ & $\mathbf{1 5 . 5 3 6 *}$ & 2.830 \\
\hline $\begin{array}{l}\text { Number of } \\
\text { Dependents }\end{array}$ & $\mathbf{1 1 . 8 8 3} * *$ & $\mathbf{6 . 8 8 8 *}$ & 1.040 \\
\hline
\end{tabular}

Note: * Significant at $5 \%$ level, ** Significant at $1 \%$ Level Chi-square analysis was performed to understand the association between association between knowledge, satisfaction, awareness of Jan Aushadhi Medical Stores with respect to Demographic Variables of the Respondents. The results of the analysis were presented in the above Table -6 .

- It is found that there is significant association between Knowledge Level about Generic Medicine with respect to Demographic Variables viz., Gender $\left(\chi^{2}=4.091, \mathrm{P}\right.$ $<0.05)$, Age $\left(\chi^{2}=8.961, \mathrm{P}<0.05\right)$, Education $\left(\chi^{2}=\right.$ 66.104, $\mathrm{P}<0.01)$, Family Income $\left(\chi^{2}=16.705, \mathrm{P}<0.01\right)$, Number of Dependents $\left(\chi^{2}=\mathbf{1 1 . 8 8 3}, \mathrm{P}<0.01\right)$ at $1 \%$ and $5 \%$ level of significance at respectively.

- It is found that there is significant association between Level of Customer Satisfaction with respect to Demographic Variables viz., Gender $\left(\chi^{2}=5.714, \mathrm{P}\right.$ $<0.05)$, Age $\left(\chi^{2}=7.500, \mathrm{P}<0.05\right)$, Education $\left(\chi^{2}=12.755\right.$, $\mathrm{P}<0.01)$, Family Income $\left(\chi^{2}=\mathbf{1 5 . 5 3 6}, \mathrm{P}<0.01\right)$, Number of Dependents $\left(\chi^{2}=\mathbf{6 . 8 8 8}, \mathrm{P}<0.05\right)$ at $1 \%$ and $5 \%$ level of significance at respectively.

- It is found that there is significant association between Awareness of Jan Aushadhi Stores with respect to Demographic Variables viz., Age $\left(\chi^{2}=6.677, \mathrm{P}<0.05\right)$ but not with Gender $\left(\chi^{2}=0.121, \mathrm{P}>0.05\right)$, Education $\left(\chi^{2}\right.$ $=5.252, \mathrm{P}<0.05)$, Family Income $\left(\chi^{2}=2.830, \mathrm{P}<0.05\right)$,

Number of Dependents $\left(\chi^{2}=1.040, \mathrm{P}<0.05\right)$ at $1 \%$ and

$5 \%$ level of significance at respectively.

Association between Pricing Policy of Jan Aushadhi Stores with respect to Satisfaction Level, Knowledge level of Generic Medicines and Awareness Level of Jan Aushadhi Stores

Table 7: Results of Chi - Square test on Pricing Policy of Jan Aushadhi Stores with respect to Satisfaction Level, Knowledge level of Generic Medicines and Awareness Level of Jan Aushadhi Stores

\begin{tabular}{|c|c|c|c|}
\hline $\begin{array}{c}\text { Pricing Policy of Jan } \\
\text { Aushadhi Stores }\end{array}$ & $\begin{array}{c}\text { Chi-S } \\
\text { quare } \\
\text { Value }\end{array}$ & df & $\boldsymbol{p}$ Value \\
\hline Level of Satisfaction & 13.821 & 3 & $\mathbf{0 . 0 0 3} * *$ \\
\hline $\begin{array}{c}\text { Knowledge Level of } \\
\text { Generic Medicine }\end{array}$ & 23.318 & 3 & $\begin{array}{c}< \\
\mathbf{0 . 0 0 1} * *\end{array}$ \\
\hline Brand Awareness & $3.732^{\mathrm{a}}$ & 3 & 0.292 \\
\hline
\end{tabular}

Chi-square analysis was performed to understand the association between association between knowledge, satisfaction, awareness of Jan Aushadhi Medical Stores with respect to pricing policy of Jan Aushadhi Medical Stores. The results of the analysis were presented in the above table 7.The result revealed that there is a significant association between pricing policy of Jan Aushadhi stores with respect to the level of satisfaction $\left(\chi^{2}=13.821, \mathrm{P}<0.01\right)$ and the knowledge level of generic medicine $\left(\chi^{2}=23.381, \mathrm{P}<0.01\right)$. But, there is no significant association between Brand awareness and pricing policy of Jan Aushadhi medical Stores because the consumer may aware of the stores, but they are not relying on Jan Aushadhi Stores.

\section{MANAGERIAL IMPLICATION AND CONCLUSION}

- Jan Aushadhi medical stores should focus on customer services to satisfy customer and to build strong relationship with customers to increase the market share.

- They should conduct a periodical survey to understand the level of customer satisfaction and their purchase pattern in the store.

- The results indicatedthat behaviour of the employee is negatively impacted on customer satisfaction. So, it is important to organised training and development programme to the employees who were working in the Jan Aushadhi Medical Stores. The training will employee to behave properly with the customers, provide high quality services and gain customer trust to improve their store patronage.

- The government also take steps in gathering data from the customers to maintain their information to communicate regularly to meet their needs and wants. Thus, increase customer satisfaction and also help in build building. 
- As like private pharmacies, the Jan Aushadhi Medicine stores also need to facilitate customers' loyalty program in the pharmacies sector, including providing advice over the phone or delivery of their needs to homes in necessary cases.

- To build strong brand and customer relationship, the pharmacy should develop its visibility through social media. They should increase their working hours. The stores should need develop complaints and suggestions system in pharmacies.

- Government should open as many outlets nearer all the major hospital and develop their distribution system effectively to connect with the people all the times.

- Government should also ensure availability of stocks in all the stores by tracking system.

- Understanding the demographic profile of consumers such as gender, age, education, income group help the marketers to work on consumer engagement.

- Marketers need to take efforts on creating brand awareness program.

- The Jan Aushadhi Stores marketers need to promote the store by using the low-cost pricing policy to create awareness about the brand.

- The government also need to invest on promotions by way of both online and offline platforms to increase the brand visibility and awareness among consumers.

- The government also need to organise awareness programme to educate about availability of generic medicines across nation to general public.

\section{REFERENCES}

1. Parasuraman, A., Zeithaml, V. A., \& Berry, L. L. (1985). A conceptual model of service quality and its implications for future research. the Journal of Marketing, 41-50.

2. Parasuraman, A., Zeithaml, V. A., \& Berry, L. L. (1988). Perceptions of Service Quality. Journal of Retailing, 64(1), 12.

3. Alhuwitat, M. A., \& Salem, F. S. H. (2017). The impact of pharmaceutical services quality on building a strong relationship between pharmacists and their customers. International journal of pharmaceutical sciences and research, 8(7), 3138-3145.

4. Lee, S., Godwin, O. P., Kim, K., \& Lee, E. (2015). Predictive factors of patient satisfaction with pharmacy services in South Korea: A cross-sectional study of national-level data. PloS one, 10(11), e0142269.

5. Bahrinizadeh, M., Esmaiilpoor, M., \&Haraghi, M. (2014). Brand Equity and Country of Origin Model in Pharmaceutical Industry. Kuwait Chapter of the Arabian Journal of Business and Management Review, 3(6), 137

6. Hassali, M. A., Shafie, A. A., Jamshed, S., Ibrahim, M. I., \&Awaisu, A. (2009). Consumers' views on generic medicines: a review of the literature. International Journal of Pharmacy Practice, 17(2), 79-88.

7. https://www.hindustantimes.com/india-news/affordable-drug-stores-to-b e-set-up-across-the-country/story-XU5YMbe4fqfXF1GMeRs5sO.ht $\mathrm{ml}$

8. http://www.who.int/gender-equity-rights/understanding/accessibility-def inition/en/

9. http://pib.nic.in/newsite/PrintRelease.aspx?relid=123443. 